\title{
Detection Antibiotic Resistance of Enviromental Bacterial Strains
}

\author{
Huda Zuheir Majeed ${ }^{a}$, Faris Nabeeh Jaafar ${ }^{b}$, Mohammed Twffeek Abdul

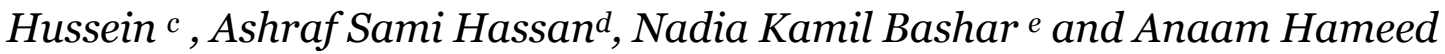 \\ Batahf \\ a,b,c,d,e,f Biology Dep. - College of Science-Al-Mustansiriyah University \\ Corresponding author :hudazuheir@yahoo.com \\ ashrafhassan_bio@yahoo.com
}

Keywords: Environmental strain, Enterococcus, Vancomycin \& Teicoplanin.

\begin{abstract}
Antibiotics are randomly prescribed for veterinary and human medication. Antibiotics by little number are used by human, animals are digested uncompletely in their digestive system and ended up in communal sewage and hospitals, eventually discharge in environmental water sources directly with no processing.
\end{abstract}

Water itself consider as major factor of dispersal of bacteria between different environmental components. Besides, bacteria had transferable genetic mobile elements to different sites of soil, water and humans.

Environmental swabs were collected locally including 50 swabs of hospital environment , 15 samples of poultry feces and chicken guts , 20 sample of heavy water and 15 sample of fish tank to identify16 isolate of Staphylococcus (4 isolate of Staphylococus aureus and 12 isolate of coagulase -ve Staphylococcus) , 19 isolate of Enterococcus spp., 7 isolates of Pseudomonas and 5 environment isolates for each Shigella spp. and Salmonella spp. .

Teicoplanin and Vancomycin sensitivity test of isolates was done, showing that 2out of 16 isolates of Staphylococcus (12.5\%) were Vancomycin-resistant , and 3out of 19 isolates of Enterococcus (15.7 \%) were Vancomycin-resistant, while the rest of isolates were Vancomycin- sensitive. From other side, all 
isolates was Teicoplanin- sensitive except only 1 Enterococcus spp. Isolate which was intermediate. The range of the Vancomycin MIC were $(6-64) \mu \mathrm{g} / \mathrm{ml}$. Vancomycin resistant isolates, showed that some isolates have one plasmid band after Extraction of their DNA.

\section{Introduction}

WHO declared that "Combat antibiotic resistant : no decision now, no treatment tomorrow" [1]. Recently, antibiotic resistance represent a dangerous problem to therapy of patients due to gowning mortal ty and morbid ty, long hospital residence, and huge economic loss to both patient and government [2].

The medical isolates such as Enterococci specifically Vancomycin Resistant Enterococci (VRE), Ps. aeruginosa, Methicillin Resistant Stap.aureus (MRSA) and members of Family Enterobacteriaceae showed resistance to drugs and dispersed in the hospital environment [3].

The microbial quality of water sources are controlled depending on faecal bacteria indicator such as Enterococcus spp., Escherichia coli which are resident of animal's alimentary tract. Besides, polluted sediments and surface waters may contain different pathogenic microorganisms including bacteria, viruses and protozoa [4].

Also bacteria of Pseudomonas genus are present-day in water soil and sediment. Pseudomonas spp. had the capacity of keeping alive in the water for prelonged time, genes encoding to resistance transferred enormously and transferrable genetic factors and causing many dangerous humans infections [5].

Staph. aureus is the responsible of skin, blood and lung infections of human. Nosocomial infections treatment by popular antibiotics are not responsive leading to use Teicoplanin and Vancomycin because they are both most powerful antibiotics of these bacterial infection, But Vancomycin is toxic mostly to kidneys [6].

Threaten infections of life caused by Gram positive bacteria are treated by Vancomycin, which considered as last choice of antibiotics used in the treatment. Vancomycin appeared in the 1950s, then used after the emergence of methicillinresistant Staphylococci infections at 1980s [7].

Both Vancomycin (a glycopeptide) and Teicoplanin (a lipoglycopeptide) had bacteriocidal activity by inhibition of peptidoglycan synthesis of the cell wall of bacteria. Although they had the same effect except that Van B Vancomycinresistant enterococci that are Teicoplanin- sensitive [8]. 
Due to rara local studies antibiotic resistance of environmental strains to most effective antibiotics Teicoplanin and Vancomycin, the study came to detect the resistance of the isolated bacteria from local environment for the above two antibiotics.

\section{Materials and Methods}

\section{1-Environmental bacterial isolates :}

One hundered environmental samples were collected including 50 swabs from hospital (beds, laundries , ear, nose and throat unit , kidney unit , preterm infants of Specialist Surgery Hospital in Baghdad) and 15 sample from poultry feces and chicken guts and 20 samples of heavy water and 15 swabs from Fish tanks (including fish gills, scales, eggs, seminal fluid and fish tank itself) to detect environmental strains of bacteria.

Samples were cultured on nutrient agar ,blood agar then into selective medium (e.g. Pseudomonas agar, Bile Esculine agar, Mannitol Salt medium , EJ agar and Chrom agar) in order to identification of isolates depending on microscopic and cultural characteristics, then doing number of biochemical tests such as Coagulase production test as mentioned at [9].

Bacterial isolates were exposed to microscopic examination to examine shape ,arrangement and reaction to Gram stain [9].

\section{2- Antibiotic sensitivity test to Vancomycin \& Teicoplanin}

It was done to the environmental isolates by disc method on Mueller Hinton agar, then resistance recorded depending of standard diameter of CLIS [10].

\section{3- Detection of Minimum Inhibition Concentration of Vancomycin}

It was detected by serial dilution method in solid media [11].

\section{4- Isolation of bacterial DNA}

Vancomycin-resistant bacteria were used to get their DNA by DNA extraction kit (Promega,USA) from identified bacterial isolates and electrophoresis was done by Agarose (0.8 \%).

\section{Results and Discussion}

After collection of swabs, identification of 16 isolate of Staphylococcus (4 isolate of Staphylococcus aureus and 12 isolate of coagulase -ve Staphylococcus), 19 isolate of Enterococcus spp. , 7 isolates of Pseudomonas and 5 isolates of both 
Salmonella spp. and Shigella spp. as environmental isolates was done as mentioned in Figure 1.

Identification of bacterial isolates was done depending on their morphological characteristics and microscopical examination as mentioned at [9] .

For Enterococcus spp. , the microscopic examination for swabs prepared from its isolates by Gram stain that they were single cocci or elongated oval or in pairs ,short G +ve chains, non-spore former. After samples culture on EJ agar , all their isolates on this medium were as so small colonies , transparent ,high circular edges, while there isolates were opaque on Bile Esculin Agar because they can analyze Esculin, this was compatible with [12].

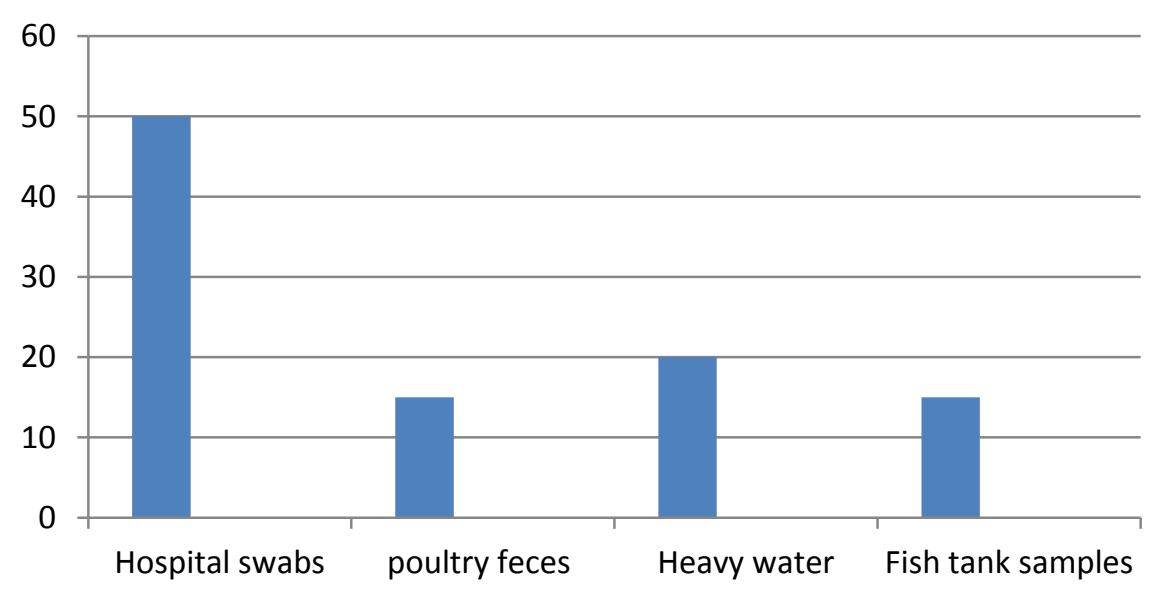

\section{Figure 1 : Environmental isolates distribution}

Antibiotic sensitivity test was done to all environmental isolates for Vancomycin \& Teicoplanin . Results showed that all environmental isolates were Vancomycin-sensitive except 2 isolates of Staphylococcus spp. (12.5\%) were Vancomycin-resistant and 3 isolates of Enterococcus were Vancomycin-resistant (15.7\%). All isolates were sensitive to Teicoplanin except 1 isolate of Enterococcus which was moderate resistant.

The least Inhibition Concentration of Vancomycin of the environmental isolates was done, showing resistance to this antibiotic by discs method, MIC was between (6-64) $\mu \mathrm{g} / \mathrm{ml}$ as mentioned at Table 1 .

Human activities created the water cycle in urban, including different components (waste-water, surface-water, drinking-water), among them hypothetically germs could be transferred. Hence, bacterial cells can transferred 
in several water bodies (such as heavy water) and clean water environments (such as disinfected water and spring drinking water) and reach humans finally [13].

Pathogens isolated of water are pathogens of enteritis (e.g. entero-toxigenic Escherichia coli, Salmonella spp., Shigella spp., etc... are mostly isolated and causing different diseases e.g. diarrhea, dysentery, and enteric fever. The enteric bacteria causing diseases had genes encoding for antibiotic resistance [14]. Bacteria which had the high - resistance character were environmental isolates, due to presence of store of many dissimilar powerful antibiotics and bacterial isolates which had resistantce to drugs are found in water sources [15].

Dangerous environmental problems represented by bacterial resistance and genes from different sources, antibiotics use by human randomly, animals and faming uses all are currently recorded [16]. Resistance of antibiotic is worldwide global threat with crucial humanity, policy and economical side effects especially new combination of antibiotic resistance could easily transfer internationally and between countries [17].

The important problem of the environment in the creation and dispersal of genes of antibiotic- resistant is growing as more than can be imagine, on the contrary the general idea that on hospital-acquired antibiotic resistance [18].

Water bodies are best niches for the dispersal and gathering of thrown antibiotics a nd are recorded for dispersal of antibiotic resistance genes . Human antibiotic use, medication of animals, industry of pharmacy, discharge with wastes of human and animal are responsible of increasing antimicrobialresistant genes dispersal problem [19].

[20] found that Vancomycin resistance genes of Enterococcus that were Vancomycin resistant, had match with that genes of Vancomycin resistant Enterococcus which were isolated from dogs infected by Urinary tract infection in USA. This refers to exchange in resistance factor between strains, even if isolated from another organism, This led to think that animals which are close to human may play a role in resistance factors dispersal, then reaching to human.

Two plasmids pSL1 and pSL2 of Enterococcus faecalis were isolated from human and chicken, this means that there were exchange in genetic information between strains either isolated from human or chicken which consider as resvoir for Vancomycin resistant Enterococcus and refers to horizontal transfer of multidrug resistant gene including Vancomycin from animal to human by responsive plasmids to sex phormones [21]. 
Table 1 MIC of Vancmycin of environmental isolates

\begin{tabular}{|c|c|}
\hline Isolate No. & $\mathrm{MIC}(\mu \mathrm{g} / \mathrm{ml})$ \\
\hline Staphylococcus 1 & 16 \\
\hline Staphylococcus 2 & 6 \\
\hline Enterococcus 1 & 64 \\
\hline Enterococcus 2 & 32 \\
\hline Enterococcus 3 & 64 \\
\hline
\end{tabular}

These strains still appear when detection was done in foods or animal feces which considered as a store of genes resbonsible of antibiotic resistance from from animal strains to human strains, this transfer occur mainly inside human guts, which is more subjected to Vancomycin resistant Enterococcus from animals by eating animal products or direct dealing with animals that take antibiotics as growth stimulators[22].

Units of intensive care besides hospitals considered as the major store for transfer of this bacteria whether for resident patients who take therapy for long time and even for healthy persons, The most healthy persons subjected to colonization of this bacteria are the workers of health care field which were hosts capable of transferring this bacteria by contaminated hands to people with their families and visitors, leading to gradually propagation of the problem [22].

Use of antibiotics by human use for breeding fowl and fish, medical uses for human and veterinary, could be at the cause of the high resistance level in environmental isolates [23]. Hospitals consider as an important environments for the bacterial resistance selection, or of genetic determinants transfer, antibiotics used and dispersal to the environmente. Hospital dispersal enterococci occurs in by contact with objects ,hands of healthcare persons, while it transfer by contaminated water or food [24].

From other side , study of genetic content of isolates that showed Vancomycin resistance by DNA extraction kit, The electrophoresis result showed that some strains had one plasmid band while the rest of isolates were empty from plasmid bands, this leads to the necessity of making a detailed genetic study and use modern techniques to identify the sites of genes responsible of Vancomycin \& Teicoplanin between local isolates from environment.

Spread of drug-resistant bacteria in the environment may be the result of transfer genes parallelly, selective pressure caused by different contaminants (e.g. biocides, antibiotics and metals) in the environment, mutation and recombination of genes[25]. 
Vancomycin-resistant Enterococcus spread could be explained by spread of isolates especially that contain van A gene which found on Transposon Tn1546 is antibiotics use as stimulator of animal growth added to food to increase their growth rates [4].

Antibiotics usage improbably led to problems of drug-resistance. Although Vancomycin considered as the last choice antibiotic, people must be aware from its harmful side effects. Besides narrow consummation for veterinary uses, due to human use, unsuitable injection for animals , Vancomycin-resistant Enterococcus presence and ease transfer of Vancomycin-resistant genes spread to Gram + bacteria [7]. Although all these precautions, Vancomycin still considered important treatment for veterinary medinine especially for multi-drug resistant Enterococcus and Staphylococcus spp. Infections.

If it could quantify the genes encoding for antibiotic resistance in water systems, it will simplify the arrangements for antibiotics in human, veterinary, farming uses leading to adoption more efficient ways to limit resistance distribution[4].

Devarajan et al.,2016 found that hospitals and waste water drainage to rivers cause spread of many pathogenic resist able bacteria , thus easily cause spread of transferable genetic elements to other environmental isolates.

\section{References}

[1] Antimicrobial resistance, for more information, go to (2011).URL www.who.int/worldhealth-day

[2] H. C. Wegener, F. M. Aarestrup, L. B. Jensen, A. Hammerum, F. Bager, of antimicrobial growth promoters in fo,od an-imals and enterococcus faecium resistance to therapeutic antimcrobial drug in europe, J. Emerg. Infect. Dis 5 (3) (1999) 329-335.

[3] E. Morales, F. S. Cots, Hospital costs of nosocomial multi-drug resistant ps. aeruginosa acquisition, BMC Health Services Research 12 (1) (2012) 122.

[4] S. Basak, P. Singh, M. Rajurkar, Multi drug resist nt and extensive drug resistance bacteria: a study: A study, J. Pathogens (2016) 1-5Article ID 4065603.

[5] N. Devarajan, A. Laffite, C. Mulaji, J. Otamonga, P. T., J. Mubedi, K. Prabakar, B. Ibelings, Occ urren of antibi tic resista ce genes and bacter al markers in a tropic,l river recei,ing hospital and urb an waste waters., PLoS One. 11 (2), e0149211.

[6] A. Spindler, L. M. Otton, D. Fuentefria, $\beta$-lactams resista,ce and presence of clase 1 integron in pseu- domonas spp. isol,ted from un treated hosp,ital effluent;ts in brazil. antonie van, Antonie van Leeuwen- hoek 102 (1) (2012) 73-81.

[7] A. B. Cavalcanti, A. R. Goncalves, C. S. Almeida, D. Bugano, Teicoplanin versus vancomycin for proven or suspected infection (review), John Wiley and Sons (Publisher), Ltd (6) (2010) 2-6, pp.

[8] P. Wijesekara, W. Kumbukgolla, J. Jayaweera, Revie,w on usa of vancom,ycin in livestock and hu,mans: Maintaining i:ts efficacy, prev:ention of resista,nce and alternat,ive therapy, Vet. Sci.2017. 4 (6).

[9] R. G. Finch, Eliopoulos, Antimicrobi. Chemotheres 55 (Suppl. 2) ii5-ii13.

[10] B. A. Ores, D. Sah, and scotts: Diagnostic microbiologymosby,inc, 12th Edition, Mosby,Inc. Baltimore, USA, 2007, pp. 266-277.

[11]Performance stand,ards for antiomicrobial suscepti.bility testin-g, CLSI, Wayne, 
Pennsylvania, USA 100 (2009) 29-3, 19th supplement, CLSI document M100-S19.

[12] A. A. F, A. I. J, M. F.M, Isolation of s.aureus bacteria resistance to high - grade vancomycin-hlr vrsa in baghdad, Journal of the Faculty of Basic Education 77 (2012) 795-80o.

[13] F. B.A., D. Sahm, Bailly and scot s diagnostic microbiology, 11th Edition, Vol. 236, Mosby, Inc, Baltimore, pp. 302-309.

[14] O. Vaz-Moreira, I. Nunes, Bacte rial diversi ty and antibiot ic resista nce in wa.ter habitats: searc.hing the lin ks with the hu,man microbe.ome, FEMS Microbiol. Rev 38 (2014) 761-18.

[15] B. Sharma, Incid ence of multi-drug resista,nce in e. coli str ains isol,ated from three la,kes of tourist attar,ction (m,irik lake, jorepok.hani lake and nakh-apani lake) of darjee-ling hills, India. Indian J. Fundam. Appl. Life Sci 2 (2012)108-14.

[16] M. Chitanand, T. Kadam, G. Gyananath, N. Totewad, D. ; Balhal, Multipl-e antibio,tic resistanceind-exing of coliforms to id,entify high risk contamina-tion sites in aq-uatic environment, Indian J Microbiology 50 (2010) 216-20.

[17] undefined Kummerer, Resistance in the environment, J Antimicrob. Chemoth 54 (2) (2004) 311-20.

[18] Antimicrobial resistance

(2014).URLhttp://www.who.int/drugresistance/documents/surveillancereport/ en/:WHOLibraryCataloguing-in-PublicationData.

[19] M. R. Gillings, Evolutionary consequences of antibiotic use for the resistome, mobilome and microbial pangenome, Front. Microbiol 4 (4) (2013) 1-10.

[20] G. Cheng, Y. Hu, Y. Yin, X. Yang, C. Xiang, B. Wang, Y. Chen, F. Yang, F. Lei, N. Wu, Functional screening of antibiotic resistance genes from human gut microbiota reveals a novel gene fusion, FEMS Microbiol. Lett 336 (2012)11-16.

[21] S. Simjee, D. G. White, P. F. McDermott, D. D. Wagner, M. J. Zervos, S. M. Donabedian, L. L. English,

J. W. Hayes, Characterization of tn1546 in va,ncomycin-resi,stant enterococcus faecium isolated from canin urinary tract infections: Evidence of gene exchange between human andanimal enterococci, J. Clin. Microbiol 12 (2002) 4659-4665.

[22] S. K. Lim, K. Tanimoto, K. Tanimoto, Y. Tomita, H. \&Ike, Pheromone- responsive conjugative van- comy,cin resista.nce plasm.ids in ent. faecalis isolat from humans and chcken feceses,

J. Appl. Environ

.Microbiol 72 (10).

URL 6544-6553

[23] K. H. Dahl, D. D. Mater, M. J. Flores, P. J. Johnsen, T. Midtvedt, G. Corthier, A. Sundsfjord, Transfer of plasmid and chromosom glycopeptide resistance determinant occur more readily in the digestive tract of mice than in vitro and exconjugants can persist stably in vivo in the absence of glycopeptide selection,

J. Antimicrob. Agent. Chemother 59(3) 478-486.

[24] J. L. Martinez, Environmental pollution by antibiotics and by antibiotic resistance determinants, En- viron. Pollut 157 (2009) 2893-2902.

[25] C.-R. G. ., Mazari-H.M., S. Ponce de Leon, R. Amieva Fernández, Agis-juarez ,r.a. ; huebner, j. and lópez-vidal, y. (2013).comparison of e faecium and e. faecalis strains i solated from wa-ter and clinical sam ples: antimicrobial susc eptibility and gene,tic relationships, PLoS One 8 (4) (2013) e59491. 


\section{الكثف عن مقاومه العزلات البكتيرية البيئية للمضادات الحيوية}

هدى زهير مجيد' ، فراس نبيه جعفر” ، محمد توفيق عبد الحسين" ، اشرف سامي حسن؛ ، ناديه كامل بشار و انعام حميا بطاح'

4،، ؛، ז،r، أقسم علوم الحياه- كليه العلوم- الجامعة المستنصرية

الخلاصة

المضادات الحيويه توصف بشكل عشوائي للعلاج البشري و البيطري. هنالك عدد قليل من المضادات الحيوية المستعملة من قبل البشر والحيوانات تهضم بشكل غير تام في الجهاز الهضمي وتتنهي في نظام التصريف و المستشفيات وفي النهايه تطرح الى مصادر المياه في البيئه مباشره دونما ابي معالجه.

ان المياه نفسها تعتبر عامل رئيسي في نشر البكتريا بين مكونات البيئه المختلفه ، اضافه الى احتواء البكتريا على عناصر ور اثيه قابله للانتقال بين اماكن مختلفه من التربه، المياه و البشر.

جمعت مسحات بيئيه محليا متضمنه ،0 مسحه من بيئه المستشفى ،0 امسحه من مخلفات الدواجن واحشاء الدجاج، · r عينه من المياه الثقيله، 10 عينه من احواض الاسماك لتكثف عن 17 عزله من بكتريا Staphylococcus كtaphylococcus aureus restaphylococcus

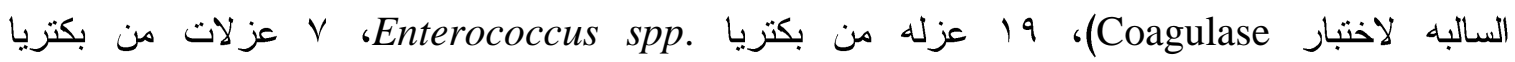
Pseudomonas و ه عز لات بيئيه لكل من بكتريا Shigella و Salmonella.

اختبار الحساسيه لمضادي التيكوبلانين و الفانكومايسين للعزلات تم اجراؤه ليظهر ان r من اصل 17 عزله

(12.5\%) من بكتريا Staphylococcus كانت مقاومه للفانكومايسين و r من اصل 9 (15 عزله(15.7\%) من بكتريا Enterococcus كانت مقاومه للفانكو مايسين ، بينما كانت بقيه العز لات حساسه للفانكو مايسين.

كل العزلات كانت حساسه لمضاد التايكوبلانين عدا عزله و احده من بكتريا . Enterococcus spp كانت متوسطه التأثز به. مدى التزكيز المثبط الادنى للفانكومايسين كان بين (ع ؟-7)مايكروغر ام/مل. اظهرت بعض العز لات البكتيريه المقاومه لمضاد الفانكومايسين حزمه بلازميديه واحده بعد استخلاص الدنا الخاص بها. الكلمات المفتاحية: العزلات البيئيه ، بكتريا Enterococcus و مضادي الفانكومايسين و التايكوبلانين. 